\title{
Albanian Federation as a Peace Factor in the Region
}

\author{
Sadri Ramabaj, PhD Cand. \\ ILIRIA University, Prishtina / Kosova
}

\begin{abstract}
The process of creating the Albanian Federation, respectively the acceleration level, is combined with the EU integration process, respectively disintegration process. Certainly, the process of creating the Albanian Federation, as a political project does not face with the challenges the European Political Union project is facing, but the approach to the EU challenges will make us more clear the process from where could be outlined the creation of Albanian Federation. Divergences between the new and older EU members, but also between the EU member states that have national heterogeneity and as consequence were not allowed to pass the Rubicon of internal self-determination, different ethnicities within national borders ( Spain, Romania, Cyprus, Slovakia and Greece ) with those who present the type of homogeneous state ( Germany, Italy, Sweden, Slovenia, etc.. ), are reflected in the attitude towards Kosovo and, generally, the right to self-determination. Comparative overview of theses of Applied Policy Research Center ( CAP, Muenchen ) on possible trends in the development of European integration processes, in relation to the process of creating Albanian Federation to the first and fifth scenario results to be small, while to the fourth scenario this possibility seems to be big. The fourth scenario, combined with elements of the second scenario, it seems to be exactly that, in current circumstances is considered the most probable to be realized, but that goes in favour of the creation process of the Albanian Federation. Creation of the Albanian Federation should be regarded as a contribution to sustainable peace in the region. Albanian Federation could play a positive role in deepening the transatlantic relationship
\end{abstract}

\section{Introduction}

The Albanian Federation establishment process and its acceleration, is actually connected with the integration or disintegration processes in the EU. Based on a parallel comparative view of five possible scenarios formulated by the Investigating Center for Applicative Policies (Centrum für angewandte Politikforschung CAP) about future of the European Union', it illuminates my aforementioned thesis. Of course, Albanian Federation establishment as a political project doesn't face the same challenges as the EU Political Project does, but challenges access toward the EU will clear up the process how Albanian Federation establishment might be delineated.

Based on my point of view, this will illuminate interdependent process of these two major projects. A comparing connection by surveying both the CAP scenario and reflection of these possible scenarios on completion of Albanian Federation, there will also be not only merely a theoretical interest. The table at the end of this chapter is the product of this comparative study.

\section{1 The first Scenario}

According to Algieri, Emmanouilids, and Maruhn the so-called Titanic Scenario describes a substantial risk of dissolving of the European Union. Based on authors of this scenario this will happen, because there will be more differences among the EU members in terms of further integration process. Divergences between the old EU members and late members will be irresistible. This heterogeneity of interests will affect the development area and it will create impassable obstacles to

Franco Algieri, Janis A. Emmanouilidis, Roman Maruhn, Europas Zukunft - 5 EU-Szenarien

Centrum für angewandte Politikforschung (C.A.P. ), München, 2003 
move together. Over expansion of the EU beyond its possibilities to cope with the current union structures will convert this union into a Political Union unable to act. The case of five EU members, which have not recognized Kosova independence, proves that the EU actually faces its own crisis to be testified as a capable structure to cope with other challenges in the Old Continent.

Based on this scenario, the EU will be weaker and weaker, because there will be big economic and social crises within the EU. Particular members of the EU will not be able to cope with these crises. Inside political and social national system crises will affect inside the EU, in fact they will be noticed by citizens' attitude towards the EU. Populist and outsideparliamentary political powers that will strongly raise their voice against Brussels' policy may be important in national political life and they will be reflected at the EU level. Divergences will continuously produce political crises coming with political disagreement values, which would cause tendencies on political return from supra-national into national structures. This crisis will inevitably have an impact on economy. Financial crisis in Greece and its possible expansion to Portugal, Spain, Ireland, Italy and so on, it seems it gives a basis to this thesis.

The EU political substance loss will be followed with the EU role weakening as an element in action race in relation to North America and Asia.

When the integration process will be completed, Monetary Union will come to an end as well as the EU symbol and the Euro currency will be substituted with national currencies.

There are chances that this scenario will impose an authentic political awakening which will be acceleration and may look like a somnambular revival.

The increasing differences among the EU members, which are not simply connected to integration processes, were visible in relation to policies, which the EU should have towards Kosova. This difference in political points of views was more considerable after the publication of the opinion of the International Court of Justice on July 22, 2010. To understand this, one needs to look at the internal changes that happened within the EU when Serbia created their resolution for the General Assembly of the UN ${ }^{1}$, right after the ICJ issued their judgement that Kosova's decleration of independence is legal internationally. Furthermore, one needs to look at the events that unfolded after Kosova's government tried to get the north of the country under control. As Weller concludes, the UN General Assembly is aware of the fact that that this judgement is not sufficient to come to an agreement between Kosova and Serbia, the General Assembly should create a resolution (Weller, p490, 2011) through which it would call to a "[... ] solution which is acceptable to both sides regarding all unresolved issues, though peaceful dialogue, in the interest of peace, security, and regional cooperation2." Even though Belgrade was pushed into not putting forth their resolution, a group of EU countries "[... ] came together to to sponzor an alternative text which would only reinforce EU's readiness to become a mediator in talks between the two countries" (Weller, p491, 2011). Serbia nonetheless never let go of its secondary plans to partition Kosova and annex the north.

Divergences among new and EU members and the EU state members with national heterogeneity did not allow internal self-determination to pass the Rubicon. The different ethnicities inside national borders (Spain, Cyprus, Slovakia and Greece) show the homogenous state type (Germany, Italy, Sweden etc. ) how this reflects on their attitude toward Kosova and self-determination.

The EU political loss of substance loss and weakening of the EU's role would create preconditions to the reviewing of the Albanian National Strategy (as a normal reflection of national strategies of current EU members) in accordance with longterm interests in relation to North America and other rising superpowers.

By the end of the European integration process, the inter-Albanian national unifying course of action would be imposed to bring the Lek as a single currency and the acceleration of an Albanian Federation as an act of establishment.

\footnotetext{
1 As expressed by the ICJ, 2010, I. The leglity of the unilateral decelration of independence by kosovo in the international law.

2 The Draft Reolution for the $77^{\text {th }}$ talking pint of the day of the $64^{\text {th }}$ UN Geeral Assembly: The request that ICJ shall give an advisory report regarding whether the unilateral decleration of independence of Kosovo is in accordance with inernational law, www.un.int/serbia/Statements/77.pdf, preemble, $2^{\text {nd }}$ paragraph. 


\section{2 The Second Scenario - The Scenario of the Closed Kernel of Europe}

It has to do with a closed kernel of European nation states, which will be functioning as a structure in themselves within EU structures.

There will be more and more different viewpoints in terms of integration processes. Based on a strategic opinion, if this process were larger, it would end with in an agreement and would transform the EU into a Federal Political Union.

The EU's incapacity to act accordingly, despite its expansion, will induce disappointment in its citizens in relations to the concept of a united Europe. Emphatic national and regional identity will be more important in citizens' conscious and their political formation. Political parties considering citizens' interests should follow this trend. All this has been concluded by Algieri, Emmanouilidis, and Maruhn in their study.

However, there will be much more common inter-trade priorities, greater possibilities of movement, goods and circulation of human ideas. Nevertheless, hungry politicians and realist politicians will avoid integration course efforts. Pragmatism will determine the political course and ambitious projects like a Social Union; United Army etc., will not have enough political support. Groups of strategists with friendly pro-European feelings do not have enough political visionaries.

After failing to establish the supra-national Political Union, then a small number of states will come together and commence a course of interstate co-operation. According to this thesis, this realistic course will enable these countries to widely protect their common interests. This kind of intergovernmental co-operation will be seen as the only way to protect common interests and cope with the possible superpowers.

The supra-national systems and decision-making processes are too complex. Finally, the EU will be incapable to achieve strategic goals, with initially some small countries posing an obstructive attitude towards the EU conversion into a global superpower.

A group of the EU countries may wish and will the Union to be treated as an equal structure, capable to share obligations and responsibilities in the new world order. It will become as linking knot of intergovernmental interests of European countries. This would happen even at conscious process, because any current EU member would fail at this anarchist endurance. A coalition for a common and interdependent union structure would be the best rational and political way out.

To compile a project like that dealing with the establishment of a common European kernel will come up now when political decision takers will conclude that integration process ability, in terms of foreign policy cooperation and security as a unique body, will be possible among the EU countries. This strong political desire, connected to this concept, will very much hinder national peripheral countries intercommunication. Actually, those that are EU members with other international actors in the field of defence, foreign policy and security, will weaken the structural and functional unity of the Union, as concluded by Algieri, Emmanouilidis, and Maruhn.

The establishment of a closed kernel of Europe will clearly send messages to the Albanian political element that the integration of Republic of Kosova in the EU, as long as the Lisbon Treaty will be in force and this political system will be as an inescapable process. A solution should be found through German model.

As a possible way to enter the EU structures, the Republic of Kosova would do so after having been nationally integrated. This means the establishment of an Albanian Federation and moves toward the European integration process, very much like the German Democratic Republic (GDR) when it was unified with the Federal Republic of Germany (FRG). The integration process in the field of co-operation among the EU member states, which would compose of the close kernel of Europe and the Albanian Federation, will be presented as a possible political will and mutual interest. This would testify to the growing Albanian element, its structural unity and the functional consolidation of the close kernel of Europe.

\section{3 The Third Scenario - The Monet Method}

According to this scenario, the further development of the EU will be done based on the applied model during the past decades. The EU will face internal and external challenges, partially in accordance to expansion processes and 
commensurate to world political and economical changes. The EU member states are able to correct the Union inability to act but without a will how to 'to heal' the source of problems.

Capacities and abilities to act, leading structures quality and legitimate democratic base will not have emphatic and meaningful improvements.

After this, the 'old logic' returns to different EU centres, which means the displacement of all hopes towards the Intergovernmental Conference of 2007/2008. Regardless of different rhetoric of politicians, consolidation of reform in the substantial sense is again impossible. At the same time, the political will to look for common action points and move forward again will be tested.

At this point, it would be considered the fact that divergences in the field of interests and conflict avoidance after the EU expansion eastwards have been deteriorating. In general, the common EU system acts from quite a lethargic point, it may not be said it does not move forward.

Regardless of weaknesses, the EU will not be dispersed. Common trade, the Schengen regime, Monetary Union as well as the consciousness that the European integration process has provided peace and stability to the old continent all act to keep the Union alive and united. Governments, as well as national parliaments, political parties and citizens are aware that the EU does not have an alternative model for the future.

In this situation, the European Commission will again as a political body have the role of a motor being accepted by all parties as a functional structure. In the field of foreign policy, agreements and other common Union acts, this will not be an obstacle. However, the obstacles are the lack of political will of each national government to approve Union action decisions in the international field inside the new global order and under USA leadership.

Institutional reforms detailed in the field of common security and foreign policy is insufficient to activate the strategic potential of the Union with about 500 million people.

First, Europeans are not able to improve and enable their military capacities. Considering foreign policy, defence and security, the EU will remain a non-active player and its actions are limited only inside the old continent.

After a very long period, the EU expansion process it finally comes to an end after the entering of Bulgaria, Romania and eventually Croatia. The EU will survey co-operation policies with commensurate interests of other countries connected not only with the entering of these countries in the EU as soon as possible but also to lead stimulating policies for regional cooperation, as concluded by Algieri, Emmanouilidis, and Maruhn in their study.

The Albanian element has a bitter experience with the EU's attitude and at the most crucial moments for it in the 1990s. The failure of substantial reforms necessary to cope with the growing internal and external challenges leaves the Western Balkans, and particularly the two Albanian Republics, outside its attention. The lack of political will to 'heal' ther roots of the problem, starting to caress Serbia, the country which has been destabilizing the region. This creates preconditions for Serbia to play two games at the same time. Firstly, it desires not to give up its strong will to enter the EU. Secondly, it desires to forge alliances with Russia and other Asian elements to the prejudice of peace, stability and stability in the region. This in the meantime, is harmful to the long-term orientations to transform the EU into a cohherent decision-making element - not only in this part of the continent but also in the wider arena.

After the entering of Croatia in the EU, the Union's long expansion process will have come to an end. This emboldens Serbia to turn its course towards Russia, giving clear signals for its possibilities to be treated as a decision-making element to divide zones of interest in this part of Europe. The return of Russia, whether through considerable investments in Serbian's economy or in tourism in Croatia, Montenegro, Greece and elsewhere in the Balkans, would probably totally devitalize the EU. The EU's policy review towards the Western Balkans commensurate interests connected not only to these countries entering the EU quickly, but leading to stimulating regional co-operating policies would create a predisposition to review the Albanian strategy towards internal integration. 
The political class of the Republic of Kosova would feel tightened because of inner political isolation. This is because of the risk of economic collapse, and it will outline and find a way to get out of isolation through the quick completion of the Albanian Federation project. However, it will always consider strategic interests of the EU based on regional co-operation policies.

\section{4 The Fourth Scenario - The Open Gravitational Space}

This has to do with an activation of a common method among a group of the EU member states, where a group of avantgarde countries would be constituted dealing with the integration processes inside the EU, forming a gravity kernel to lead this process.

The leadership of these countries with positive predisposition to deepen the integration course, and after having concluding there are some serious obstacles from a group of countries to move forward strong-minded with the integration course to transform the EU from an Economic Union into a Political Union, a new strategy, the so-called 'Open Gravity Space' will be compiled and presented.

Based on this avant-garde point of view, the transforming of the EU into a free trade zone and weakening of the EU principles and the marginalization of supra-national institutions (ie: the European Commission, the European Parliament) should be avoided unconditionally.

The majority part of governments, majority part of political parties at the European level and civil society, appreciate the deepening of integration processes. The strong-minded EU expansion from 27 to 28 countries, including (Croatia in July 2013) ${ }^{1}$ is ambitious. It is aiming to have this number of states in the near future, even 35 countries in total. After the entering of Western Balkans countries in the EU, this avant-garde thinking is necessary in order to be equipped with additional integration impulses. The stagnation of EU integration policies is not only harmful to long-term plans, but they are even poisonous to the abilities of the EU in coping with the difficulties of the new world order and the race in the economic field.

After having failed even before on block approval of integration policies through a more accelerated course (Schengen, Monetary Union), the flexibility on taking decisions for crucial issues in European level will be turned into an action method.

The countries of positive will and predisposition for further integration will increase their agreements indifferent fields, in accordance with basic documents of the EU (Lisbon Treaty and Legal Acts produced by this political agreement).

To legitimise this kind of action, these avant-garde states will use 'co-operation strengthening' coming from the Amsterdam Agreement as a differential instrument.

The opened gravity space, including small and big countries which entered or have recently entered in the EU, will be completing the course of transforming the EU into a Political Union. Mechanisms, structures and instruments of this area (which deepen the course of co-operation) act to enable other states to be integrated whenever they see it reasonable.

The expansion process of the EU is concentrated on the absorption of the Western Balkans countries as well as of the European economic and strong-minded area countries for integration, including Switzerland, as concluded by Algieri, Emmanouilidis, and Maruhn.

Any serious effort of the EU transformation from an economic union into a Political Union, is welcomed by Albanians. Such an effort, as it is in accordance with the long-term interests of the Albanian nation, will be fully supported by Tirana and Prishtina.

Actually, a number of the EU countries like Greece, Cyprus, Romania, Slovakia and Spain have not recognized Republic of Kosova even after International Court of Justice (See Appendix Document 2). They cause real obstacles to the EU in

\footnotetext{
1 On the $20^{\text {th }}$ aniversary of its independence Croatia got the official note informing them that the negotiating time had ended, getting them officially into the timespan of its ratification of its request. In the year 2013 it will adhere officialy into the EU. 
terms of Foreign Policy and Security as a unique body. This means a lot, considering that these are countries that pretend to accelerate the EU transformation course into a political union.

Considering this plan, the formation of an opened gravity space from a group of countries pretending to develop the integration course, this is welcomed by the Republic of Kosova and by Albanians in general.

Countries with a positive will for further development will not only increase their

agreements among themselves in different fields in accordance with the EU basic documents, but they will also look for a tactical egression inside decision of "cooperation strengthening" with third countries to keep Republic of Kosova as close to the EU as possible. This would create circumstances to adhere to European trade and to participate in other facilitated programs. In the meantime, judging the persistent action of five European countries against the recognition the of Republic of Kosova's independence and creating necessary preconditions for adherence as an equal legal entity inside the EU, this gives a signal not only to Albanian element but also to the 'Open Gravity Space' to move towards Albanian Federation establishment and its approval. This can be considered it as a necessary and natural process.

In this active kernel of the EU (Germany, France and Brussels), parallel with Poland, Czech Republic, Hungary, Slovenia, Croatia or any other country, the Albanian Federation will be a partner of this Gravity Space. As a block, the Open Gravity Space would be converted into a trailing locomotive to transform the EU into a Political Union.

This scenario seems to be the one that under the current circumstances can be seen as the most likely.

\section{5 The Fifth Scenario - Europe as a Superpower}

It has to do with the strong-minded founders of the EU to turn it into a world superpower, $\mathrm{n}$ fact, the reversion of the role of Europe as a decision-making power at a world level. In this case, the EU would maximally use its institutional and economic resources.

Even economic priorities, number of population, military potential and so on, offers the EU enough action base, let us not say imposing one.

The linear integration developments, in terms of permanent success on integration reforms' developments, is a guarantee for the Union. The increase of transparency inside the European system, as well as the reason to find solutions to internal and external challenges that the EU is facing everyday, has an impact on the EU to be accepted by Europeans.

An increased net of European society stimulates public debates of different subjects dealing with the EU. The establishing of inter-medial structures (media, different non-government organizations), have an impact on European opinion and civil society itself. Based on close feelings, in terms of the approach of European people's and feeling as Europeans, the EU will be developed in its right track and be transformed into a political union. The common citizens' initiatives at European level and cooperation of supra-national bodies in different kind of fields have an impact on Europeanization process. The EU will reach its final goal by transforming Europe into a country of its own kind.

Inside these developments, countries will convey many competences of today towards suprasupra-national bodies in Brussels. All competencies dealing with foreign and home policies, incorporating defence, economy and social policies, will be conveyed into a common body established based on the European Constitution's competencies. The EU will have more and more competencies in different fields, which are simply estimated as national competencies today. The EU bodies will show that it is more capable to sort out the different problems of citizens' than those of just national states.

The history and tradition of nation states and European regions give priority to the transformation of the EU into a superpower.

The Competencies division principle and violent execution among three powers: execution, legislation and court will have its own model for the European system. 
Based on a rule system with clear rules to control the actual system's dealing with legislation and government power, the European Commission is a powerful body with clear competencies and enforcement. The Chairperson of the Commission will be chosen directly by the people. During full enforcement of parliamentary life, both Houses, the European Parliament and European Countries' House, composed of member states, will have full action competencies - in the field of legislation and enforcement. The court's control will mainly be without limitations, they will be the European Court Competence. In this regular and clear contest of constitution financial law, the EU will be right to have its own financial resource funded by European taxpayers.

The EU development and its transformation into a European Superpower testifies that it is an open system, even when it is transformed into a political union it has a great possibilities to attract more members. However, the EU testifies to being a functioning system, but it should be expanded. As Turkey has an open way to enter the EU, finally no European country should be denied to be part of the EU. Even countries outside Europe, like Israel and Morocco, will exert significant pressure to be part if the EU.

Europe will not see this big expansion as a solidarity act only, but also as an investment in the future as well. New markets of countries adhering the EU will be automatically transformed into an economic attraction for strong economies of the old EU countries, which have qualitative and necessary products for new market.

During the transformational process of many national competences to supra-national structures in Brussels, the EU will be transforming into a respected structure in the security field. The EU stabilization, in terms of security and defence issues through the creation of the Strategic European Common Forces (SECF) having a common European command of French and British Kernel, will totally change European role at an international level.

After reforms at the UNO (United Nations Organization), the EU will have its permanent seat at the Security Council. Its action capacity at international level and growing commitment imposes a review to foreign policies in proportion to concepts of interests division inside regional blocks concerns as dominators to international order.

Nevertheless, the EU will definitely end the idea of being civilizing power and will permanently use means of international energy.

Regardless of basic changes between the superpower states of Europe as its big political and economical power, it will be able to be compared with the USA. After the conflicts of the $21^{\text {st }}$ century possible splitting the 'Transatlantic Block', Washington and Brussels may" present their interests at an international level. The creation of a political union, particularly regarding its military force and security matters, makes forces balanced inside the world system as well for a kind of parity with the USA. The establishing of the Atlantic Economic Area it will be as a symbol of a Euro Atlantic equilibrium. This is the most extraordinary potential conclusion according to Algieri, Emmanouilidis, and Maruhn.

In the efforts to transform the EU (European Union) into a world superpower and the return of Europe's role into an international relation field, the Albanians will be a real co-operating partner. The EU's institutional and economic resources would be used to facilitate the establishment of the Albanian Federation upon the integration of both Albanian Republics in the EU, while different European centres will be investing in Kosova state identity creation by interrupting strong-minded inside-national integration. Regarding this plan, as similar partnership as between Austria and Germany, which does not allow political integration, will be used.

Both Albanian republics will use their economic priorities, number of population, natural resources, seaside and minerals and so on, to be transformed into a partnership element in the region. In the EU, they will be co-operating as equal and independent entities.

Linear integration developments in the sense of permanent achievement in integration reforms guarantee success in the field of regional cooperation. In fact, having no more difficulties between the Republic of Kosova in relation to the Republic of Serbia by imposing Prishtina to review its border in the northern part in favour of Serbia.

The same process will be with Republic of Bosnia and Herzegovina, thus again transforming Serbia into a close perspective as a dominant element in the Balkans.

The good presentation of interests among the partners of 
Transatlantic Block, after the establishment of European Political Union with its military power will impose the Albanian element to review its position and to re-evaluate its interests.

Parity between the USA and European Political Union, which results with the establishment of the Atlantic Economic Area, develops integration between both Albanian Republics and Macedonia. This would turn Albanians into an establishing element in the region and inside the Atlantic Economic Area, if it is ever created after the vision, in the future.

The comparative analysis of these thesis by the Centre for Applied Policies (Centrum für angevandte Politikforschung C. A. P., München) regarding the potential developments during the development of the European integrating procesees, in its potential reprt regarding the Albanian Federation might represent such a table:

\section{Scenarios about the future of EU and the impact on the Albanian Federation}

\begin{tabular}{|c|c|c|c|c|c|}
\hline $\begin{array}{l}N \\
r\end{array}$ & Scenarios & $\begin{array}{l}\text { Probability of } \\
\text { success }\end{array}$ & $\begin{array}{l}\text { Propability of } \\
\text { failure }\end{array}$ & $\begin{array}{l}\text { Short-term } \\
\text { impact on } \\
\text { Albanian } \\
\text { Federation } \\
\text { Project }\end{array}$ & $\begin{array}{l}\text { Long-term } \\
\text { impact on } \\
\text { Albanian } \\
\text { Federation } \\
\text { Project }\end{array}$ \\
\hline 1 & The Titanic & Small & Great & Positive & Positive \\
\hline 2 & Closed Kernel of Europe & Relative & Small & Negative & Pozitive \\
\hline 3 & Monet Method & Relative & Relative & Negative & Pozitive \\
\hline 4 & Open Gravitational Space & Great & Small & Positive & Positive \\
\hline 5 & Europe as a Superpower & Small & Great & Negative & Negative \\
\hline
\end{tabular}

Fig. $n$ r. 1

\section{Conclusions}

Comparative overview of Centre for Applied Policy Research ( CAP, Muenchen ) theses on possible trends in the development of European integration processes, in relation to the process of creating Albanian Federation to the first and fifth scenario results to be small, while to the fourth scenario this possibility seems to be bigger. It is of interest to see the conclusion that coincides with the fourth scenario in terms of short term reflection on the formation of the Albanian Federation. Under the first and fourth scenario, this reflection would be anyhow positive.

Whereas long-term reflection on the process of formation of the Albanian Federation under these scenarios, excluding the fifth, is positive to all, without exception. The fourth scenario, combined with elements of the second scenario, it seems to be exactly that, in current circumstances is considered the most probable to be realized, but that goes in favour of the creation process of the Albanian Federation.

Creation of the Albanian Federation should be regarded primarily as a contribution to sustainable peace in the region. If we analyze the meeting points of these processes with the second and the fourth scenario of CAP regarding the EU 
perspective, the creation of the Albanian Federation should be perceived as a contribution of its kind in the cultivation and strengthening of the EU, and within this the transatlantic relations.

\section{Literature}

1. Franco Algieri, Janis A. EMMANOUILIDIS Roman Maruha, Zukunft Europas - 5 EU -

Szenarien, Centrum für Angewandte Politikforschung (CAP), Munich 2003

2. Marc Weller, contested citizenship: international administration of Kosovo's war for independence, Koha, second edition, Prishtina 2011

3. Advisory Opinion, 2010 , ICJ, I.

4. www. un. int/serbia/Statements/77. pdf

5. www. b92. net/info/vesti/index. phd? Yyyy $=2011 \& \mathrm{~mm}=08 \& \mathrm{dd}=23 \&$ nav_id $=\quad$ 536839; www. gazetaexpress. com/?cid=1,13. 61374

6. Sadri Ramabaja, Albanian Federation - cohesion of the nation-state and the EU, dissertation thesis, University of Peace \& UET, Tirana, 2014 